\title{
Isolation and effect of Trichoderma citrinoviride Snef1910 for the biological control of root-knot nematode, Meloidogyne incognita
}

Haiyan Fan ${ }^{1}$, Meiling Yao ${ }^{1}$, Haiming Wang ${ }^{1}$, Di Zhao ${ }^{2}$, Xiaofeng Zhu' ${ }^{1}$ Y Yuanyuan Wang ${ }^{3}$, Xiaoyu Liư ${ }^{4}$, Yuxi Duan ${ }^{1}$ and Lijie Chen ${ }^{1 *}$ (D)

\begin{abstract}
Background: Root-knot nematode is one of the most significant diseases of vegetable crops in the world. Biological control with microbial antagonists has been emerged as a promising and eco-friendly treatment to control pathogens. The aim of this study was to screen and identify novel biocontrol agents against root-knot nematode, Meloidogyne incognita.

Results: A total of 890 fungal isolates were obtained from rhizosphere soil of different crops and screened by nematicidal activity assays. Snef1910 strain showed high virulence against second stage juveniles (J2s) of M. incognita and identified as Trichoderma citrinoviride by morphology analysis and biomolecular assay. Furthermore, T. citrinoviride Snef1910 significantly inhibited egg hatching with the hatching inhibition percentages of $90.27,77.50$, and $67.06 \%$ at 48,72 , and $96 \mathrm{~h}$ after the treatment, respectively. The results of pot experiment showed that the metabolites of T. citrinoviride Snef1910 significantly decreased the number of root galls, J2s, and nematode egg masses and J2s population density in soil and significantly promoted the growth of tomato plants. In the field experiment, the biocontrol application showed that the control efficacy of T. citrinoviride Snef1910 against root-knot nematode was more than 50\%. Meanwhile, T. citrinoviride Snef1910 increased the tomato plant biomass.
\end{abstract}

Conclusions: T. citrinoviride strain Snef1910 could be used as a potential biological control agent against root-knot nematode, M. incognita.

Keywords: Fungal bioagent, Nematode disease management, Plant growth promotion, Tomato

\section{Background}

Root-knot nematode (RKN) is one of the most seriously damaging plant-parasitic nematode in the world threatening to the growth and production of more than 5500 plants, including vegetable crops and weeds [1-3]. Among them, Meloidogyne incognita, M. arenaria, M. javanica,

\footnotetext{
* Correspondence: chenlj-0210@syau.edu.cn

${ }^{1}$ Nematology Institute of Northern China, College of Plant Protection, Shenyang Agricultural University, Shenyang, China

Full list of author information is available at the end of the article
}

and M. hapla are the four main root-knot nematodes that have been reported. M. incognita is the most serious with $51 \%$ of the affected crops and the highest distribution proportion among these four species [4]. With rapidly increased developing protected agriculture, high-value crops, such as tomato (Solanum lycopersicum cultivar L402 susceptible to $M$. incognita), are severely damaged by M. incognita and has led to severe losses in China [5]. Currently, chemical and physical measures have limited use for RKN disease management. Furthermore, as the

C C The Author(s). 2020 Open Access This article is licensed under a Creative Commons Attribution 4.0 International License, which permits use, sharing, adaptation, distribution and reproduction in any medium or format, as long as you give appropriate credit to the original author(s) and the source, provide a link to the Creative Commons licence, and indicate if changes were made. The images or other third party material in this article are included in the article's Creative Commons licence, unless indicated otherwise in a credit line to the material. If material is not included in the article's Creative Commons licence and your intended use is not permitted by statutory regulation or exceeds the permitted use, you will need to obtain permission directly from the copyright holder. To view a copy of this licence, visit http://creativecommons.org/licenses/by/4.0/ The Creative Commons Public Domain Dedication waiver (http://creativecommons.org/publicdomain/zero/1.0/) applies to the data made available in this article, unless otherwise stated in a credit line to the data. 
nematicides are associated with serious environmental problems. Therefore, the safe and effective strategies for management for M. incognita are needed.

Biological control with microbial antagonists has received a great deal of attention as a promising measure to control different plant diseases [6, 7]. Many antagonistic microorganisms including Trichoderma spp., Streptomyces spp., Pseudomonas spp., Bacillus spp. have been screened and widely exploited to control a wide range of plant pathogens [8-11]. Some microorganisms have been identified as biological control agents against $M$. incognita such as Pasteuria penetrans, B. subtilis, T. harzianum and T. viride, Pochonia chlamydosporia and Purpureocillium lilacinum [12-16]. Trichoderma genus is one of the most frequently studied groups of fungi used as biological control agents. Its species are often very fast growing, rapidly colonize substrates and effectively control different diseases by using a variety of mechanisms $[17,18]$. At present, there are no reports about using $T$. citrinoviride as a biological control agent against RKN, M. incognita.

The objective of this study was to isolate effective fungal strains against $M$. incognita, evaluate the biological control activity under in vitro and in vivo, phylogenetically identify them based on morphology and sequence analysis and their effects on the growth of tomato plants in pot and field experiments.

\section{Results}

\section{Screening of antagonistic fungi}

In total, 890 fungi isolates were obtained from rhizosphere soil of different crops and screened for the potential nematicidal action against $M$. incognita in vitro (Table S1). Among these isolates, strain Snef1910 (CGMCC Accession No.13569; China General Microbiology Culture Collection Center) showed the strongest nematicidal activity against second stage juveniles (J2s) of $M$. incognita. The percentages of J2s mortality of strain Snef1910 were 93.79, 98.20, and 100\% at $24 \mathrm{~h}, 48 \mathrm{~h}$, and $72 \mathrm{~h}$, respectively (Fig. 1). Moreover, strain Snef1910 showed significant antagonistic activity in vitro towards other pathogens that caused plant diseases in wheat, cotton, melon and other plants (Table 1).

\section{Evaluation of ovicidal efficacy in vitro}

To further investigate the nematicidal activity of strain Snef1910, the ovicidal efficacy against $M$. incognita was performed. The egg hatching percentage of $M$. incognita treated with PDB medium (control) was $51.17 \%$ at $48 \mathrm{~h}$, while in treatment with strain Snef1910 culture filtrate it was $4.98 \%$ (Fig. 2). The hatch inhibition percentage of strain Snef1910 was up to $90.27 \%$ (Fig. 2). Similar results were obtained at $72 \mathrm{~h}$ and $96 \mathrm{~h}$ (Fig. 2).

\section{Identification of strain Snef 1910}

To identify strain Snef1910, morphological observation was performed. The strain Snef1910 grew rapidly on PDA medium forming a white, $60-\mathrm{mm}$-diameter colony at $25^{\circ} \mathrm{C}$ under dark for 2 days. Then, the colony changed to greyish green or dark green and formed a wide conidial zone at the edge of the colony at 7 days (Fig. 3a-c). The conidiophores were erect showing a long axis of the structure and fertile to the top. The cylindrical or spindle-shaped bottle stems were solitary born on main

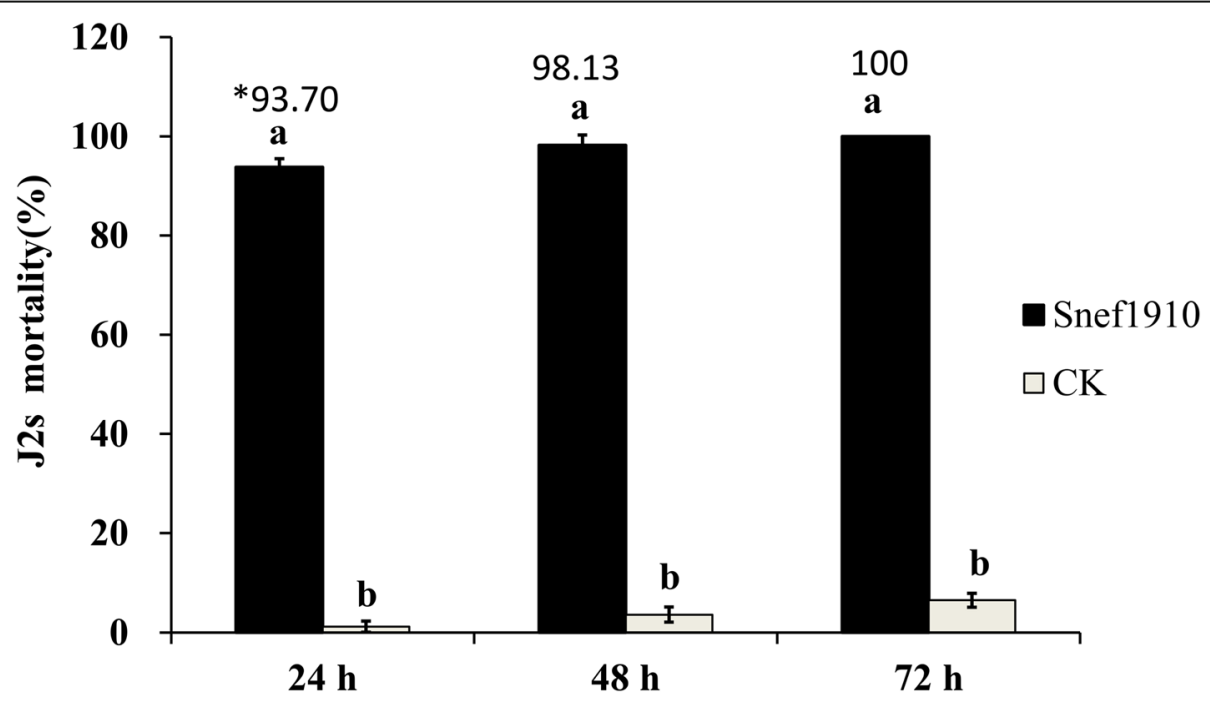

Fig. 1 The effect of strain Snef1910 on second stage juvenile (J2s) mortality of M. incognita in vitro. The J2s suspension mixed with PDB medium alone was used as control (CK). Error bars represent standard deviation. *The data on the columns represent the corrected J2s mortality. J2s mortality $(\%)=$ the number of dead $\mathrm{J} 2 \mathrm{~s} /$ total number of $\mathrm{J} 2 \mathrm{~s} \times 100$. Corrected $\mathrm{J} 2 \mathrm{~s}$ mortality $(\%)=(\mathrm{J} 2 \mathrm{~s}$ mortality in the treatment $-\mathrm{J} 2 \mathrm{~s}$ mortality in the control)/(100 - J2s mortality in the control) $\times 100$ 
Table 1 Inhibitory activity of strain Snef1910 against various fungal plant pathogens in vitro

\begin{tabular}{ll}
\hline Target fungal pathogens & the percentage of growth inhibition \\
\hline Fusarium graminearum & $60.76 \%$ \\
Fusarium oxysporum & $49.28 \%$ \\
Fusarium monihforme & $21.73 \%$ \\
Fusarium roseum & $25.20 \%$ \\
Gaeumannomyces graminis & $62.31 \%$ \\
Rizoctonia cerealis & $80.38 \%$ \\
Verticillium alboatrum & $54.87 \%$ \\
\hline
\end{tabular}

branch and spirally arranged on top of lateral branches (Fig. 3d). The conidia were yellowish green to dark green, globose with smooth walls (Fig. 3e). No distinct coconut-like odor was detected. Based on the above microscopic observations, strain Snef1910 was tentatively identified as Trichoderma.

To further identify strain Snef1910, a phylogenetic analysis of its $5.8 \mathrm{~S}$-ITS sequences was performed. The phylogenetic tree showed that the 5.8S-ITS sequence (GenBank accession number: YK964310) of strain Snef1910 was clustered with T. citrinoviride (Fig. 4). These results demonstrated that strain Snef1910 was identified as T. citrinoviride.

Biocontrol of root-knot nematode in the pot experiment In order to investigate the potential biological control activity of T. citrinoviride Snef1910 against M. incognita in vivo, tomato seedlings were treated with a fermentation broth of $T$. citrinoviride and inoculated with $\mathrm{J} 2 \mathrm{~s}$ of $M$. incognita. The number of root galls on tomato seedlings treated with PDB culture medium (PDB culture medium-inoculated) was 47.35 , thirty days post-inoculation of $M$. incognita, while the number of root galls on tomato seedlings treated with fermentation broth of $T$. citrinoviride Snef1910 and untreated were 16.05 and 48.15, respectively (Table 2). The number of root galls on tomato seedlings treated with T. citrinoviride Snef1910 was reduced by 66.10\% compared with that of the PDB culture mediuminoculated (Table 2). T. citrinoviride Snef1910 caused significant decreases in the number of egg masses and J2s on tomato seedling root, which were 80.63 and $69.87 \%$ reduced, respectively, compared with those in the control (PDB culture medium-inoculated) (Table 2). Furthermore, thirty days after $M$. incognita inoculation, the number of J2s per $100 \mathrm{~mL}$ soil of $T$. citrinoviride Snef1910-treated seedlings was significantly smaller than that of the control (PDB culture medium-inoculated), with mortality reaching $77.28 \%$ (Table 2). Thirty days after treatment, $T$. citrinoviride Snef1910-treated plants exhibited increases in shoot length, root length, root fresh weight, and root dry weight by $15.61,23.32,35.08$, and $33.33 \%$, respectively, compared with untreated plants (Table 3).

Biocontrol of root-knot nematode in the field experiment The field experiments showed similar results to the greenhouse pot experiments. At 30 days after transplantation, the gall index of seedlings treated with $T$.

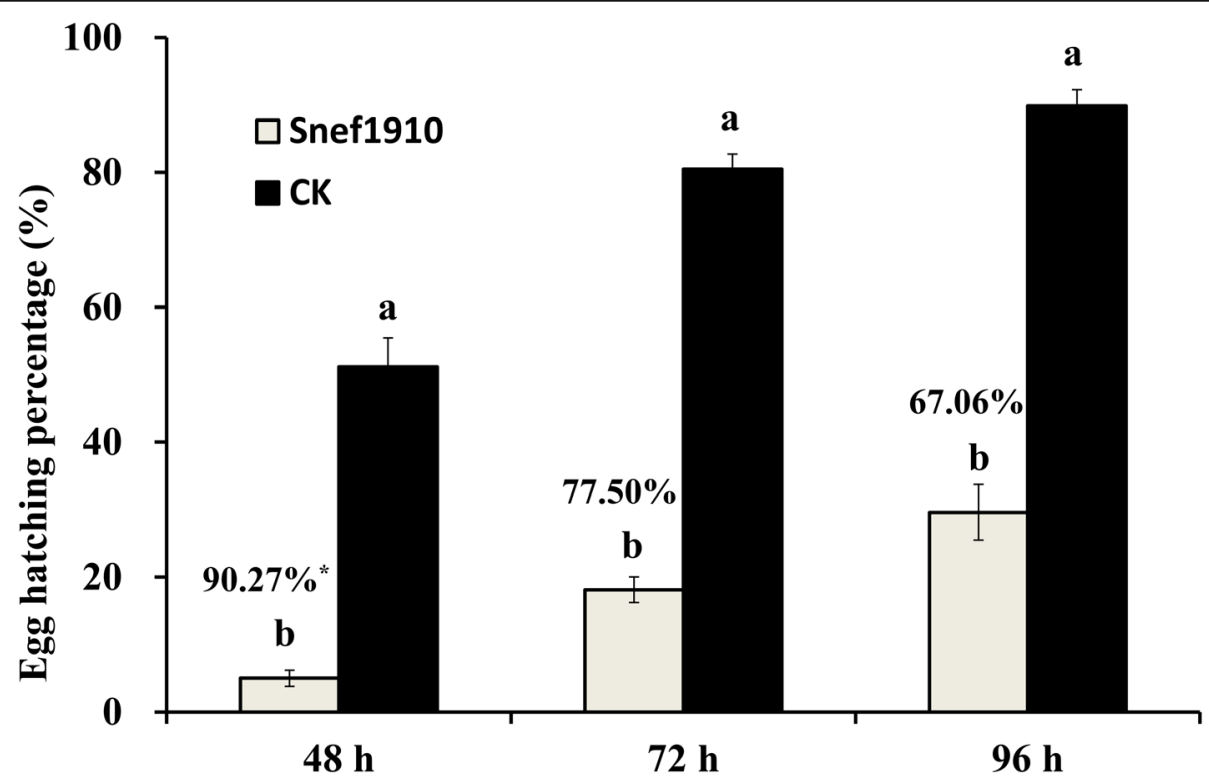

Fig. 2 The egg inhibition of M. incognita exposed to strain Snef1910 culture filtrate in vitro. CK denotes for the PDB medium. *The data on the columns represent the hatch inhibition percentage. Egg hatching percentage $(\%)=$ the number of hatched eggs/total number of eggs $\times 100$. Hatch inhibition percentage $(\%)=$ (the number of hatched eggs in the control - the number of hatched eggs in the fungus-treated group)/the number of hatched eggs in the control $\times 100$ 

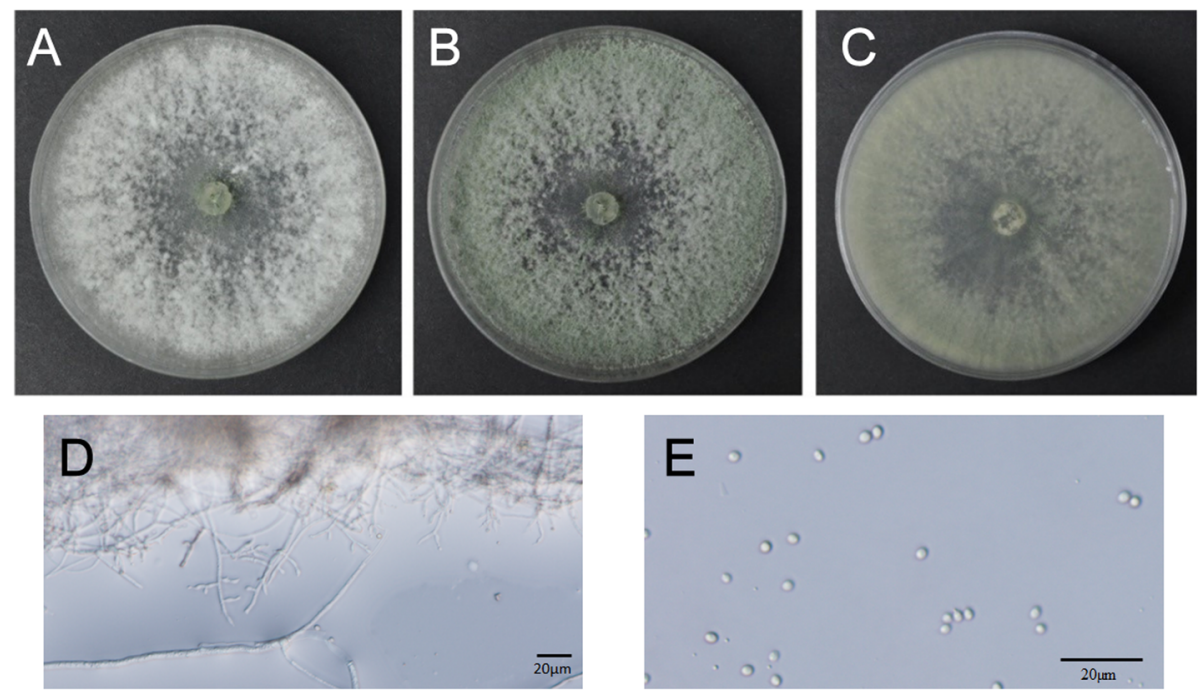

Fig. 3 Colony characteristics and conidiophores and conidia of strain Snef1910. a-c Colony appearance of strain Snef1910 grown on PDA at $25^{\circ} \mathrm{C}$ for 2-7 days. d Microscopic image showing conidiophores structures and branching pattern of strain Snef1910. e Image of conidia of strain Snef1910

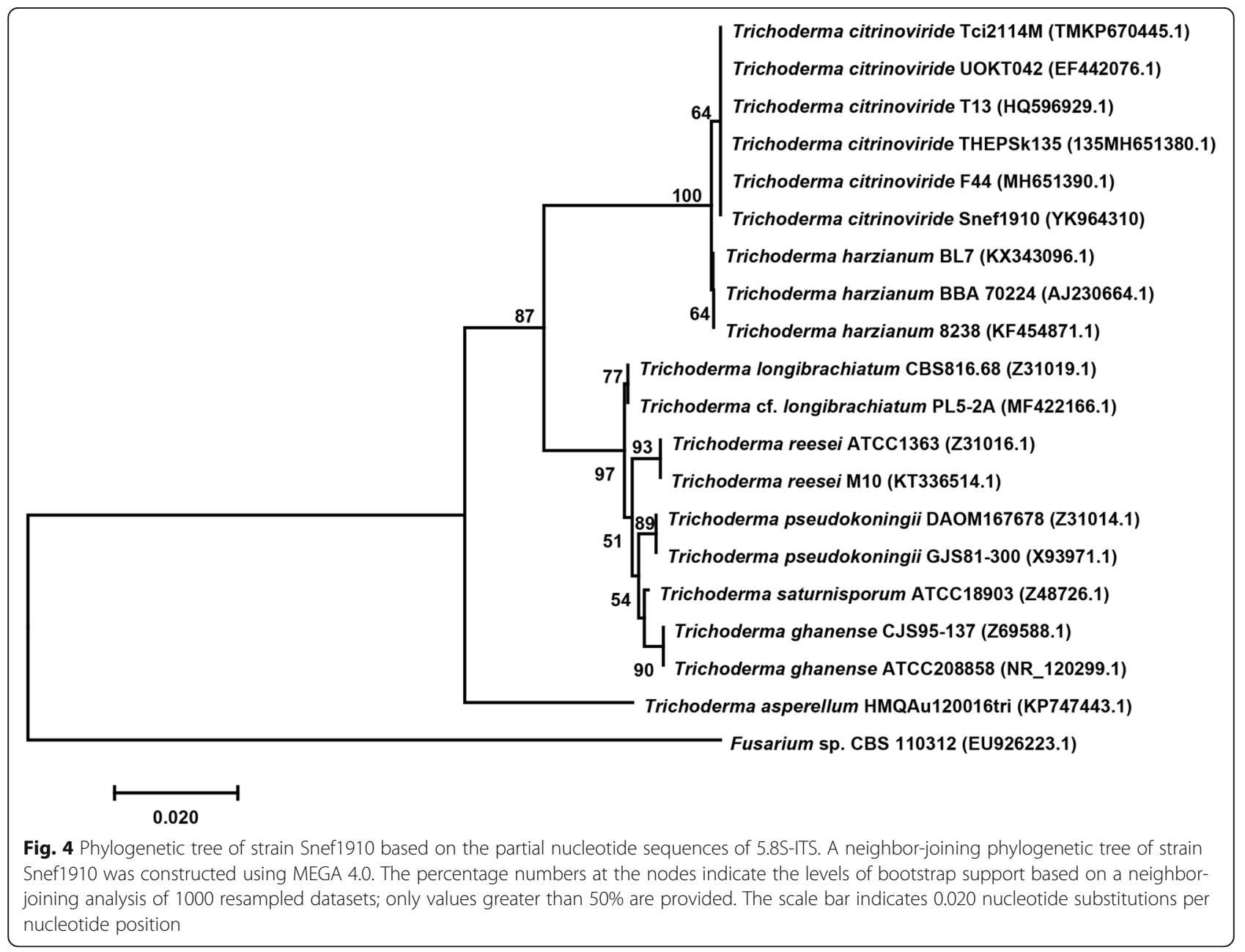


Table 2 The biological control activity of T. citrinoviride Snef1910 against M. incognita in the pot experiment with tomato plants

\begin{tabular}{lllll}
\hline Treatments & Root galls/ g root & Egg masses/ g root & Juveniles/ g root & J2s/100 ml soil \\
\hline untreated-inoculated & $48.15 \pm 5.40^{\mathrm{a}}$ & $43.85 \pm 2.90^{\mathrm{a}}$ & $65.80 \pm 3.40^{\mathrm{a}}$ & $308.30 \pm 22.33^{\mathrm{a}}$ \\
PDB culture medium-inoculated & $47.35 \pm 3.72^{\mathrm{a}}$ & $42.60 \pm 2.88^{\mathrm{a}}$ & $67.20 \pm 3.89^{\mathrm{a}}$ & $297.10 \pm 15.83^{\mathrm{a}}$ \\
Snef1910-inoculated & $16.05 \pm 2.27^{\mathrm{b}}$ & $8.25 \pm 1.62^{\mathrm{b}}$ & $20.25 \pm 2.15^{\mathrm{b}}$ & $67.50 \pm 6.35^{\mathrm{b}}$ \\
\hline
\end{tabular}

The biological control activity of $T$. citrinoviride Snef1910 against $M$. incognita in the pot experiment was determined, 30 days post-inoculation. The data are the averages \pm standard error from ten replicates. Different letters represent a significant difference at $P \leq 0.05$

citrinoviride Snef1910 were 42.67 and 37.78 while those treated with PDB (control) were 86.67 and 80.00 (Table 4) which indicated a noticeable reduction of RKN during a two-growth seasons of field experiment. Furthermore, the biocontrol efficacy of T. citrinoviride Snef1910 in controlling $M$. incognita reached up to 50.77 and $52.77 \%$ in the field experiments (Table 4; Fig. 5). These results indicated that $T$. citrinoviride Snef1910 is a biological control agent for efficiently controlling RKN. Shoot length, root length, fresh weight of root were also measured in the field experiments. The growth-promoting results in field experiments were similar to the greenhouse pot experiments. The shoot length and root length in $T$. citrinoviride Snef1910 treated plants increased by 13.48 and $17.98 \%$, respectively, in comparison with the control plants (Table 5), which suggested that T. citrinoviride Snef1910 promotes the growth of tomato. In contrast, $T$. citrinoviride Snef1910 showed a $35.62 \%$ reduction in the fresh weight of root, thirty days after transplantation (Table 5). Similar results were obtained in the second field experiment (November to December in 2019) (Table 5). These results suggested that T. citrinoviride Snef1910 has the potential in increasing tomato plant growth.

\section{Discussion}

Researches on the use of antagonistic microorganisms to suppress plant diseases are receiving increasingly attention [19]. In recent years, Trichoderma spp. has been used as biocontrol agents to control different plant pathogens $[20,21]$. Specifically, previous studies have reported that T. viride MTCC No. 167, T. asperellum T12, and T. harzianum T-78 were potential biological agents against $M$. incognita [22-25]. Furthermore, a few other microorganisms such as $S$. rubrogriseus, B. subtilis, $P$. putida and P. fluorescens have been employed in controlling M. incognita $[13,26]$. However, the microorganism sources used for the control of $M$. incognita are limited and need further explored. In this study, $T$. citrinoviride Snef1910 strain was screened from 890 fungal isolates and showed high larvicidal and ovicidal activity against $M$. incognita in vitro. Furthermore, $T$. citrinoviride Snef1910 strain significantly reduced the galls and J2s of nematodes, and promoted the growth of tomato plant in the pot and field trials. This study is the first report on the use of a T. citrinoviride strain as a potential biological control agent to control RKN disease. The results of our study provide an alternative and promising biological control agent and practical strategies for controlling RKN, M. incognita.

Trichoderma species have been reported as biological control agents in controlling RKN disease [23-25]. For example, nematode galling caused by $M$. incognita on tomato showed reductions of up to $30.8 \%$ under the soil treatments with T. harzianum and T. viride [27]. Meanwhile, $T$. harzianum can reduced galling caused by another RKN M. javanica on tomato plants [28]. In addition, the biocontrol efficacy of another species $T$. longibrachiatum in controlling $M$. incognita was indicated from 30 to $78 \%$ for gall index on cucumber [29]. In the present study, the damage of RKN can reduce over 50\%, which suggested that T. citrinoviride Snef1910 has more biocontrol efficiency and potential application to control RKN M. incognita on tomato.

Multiple action modes of Trichoderma species were reported to contribute to the biological control, including nutrient and space competition, antibiosis, mycoparasitism, and induced systemic resistance of plants [30-33]. Particularly, the antimicrobial compounds produced by Trichoderma species and their roles in controlling plant pathogens have been characterized [34-36]. For example,

Table 3 The effects of T. citrinoviride Snef1910 on the growth parameters of tomato plants in pot experiments

\begin{tabular}{lllll}
\hline Treatments & Shoot length $(\mathbf{c m})$ & Root length $(\mathbf{c m})$ & Root fresh weight (g) & Root dry weight $(\mathbf{g})$ \\
\hline untreated-uninoculated & $42.72 \pm 2.3^{\mathrm{b}}$ & $15.13 \pm 1.36^{\mathrm{b}}$ & $7.57 \pm 0.82^{\mathrm{ab}}$ & $0.80 \pm 0.08^{\mathrm{b}}$ \\
untreated-inoculated & $35.40 \pm 3.87^{\mathrm{c}}$ & $10.45 \pm 0.72^{\mathrm{c}}$ & $4.46 \pm 0.66^{\mathrm{c}}$ & $0.52 \pm 0.06^{\mathrm{c}}$ \\
PDB culture medium-inoculated & $35.89 \pm 3.43^{\mathrm{c}}$ & $11.08 \pm 1.03^{\mathrm{c}}$ & $4.57 \pm 0.75^{\mathrm{c}}$ & $0.52 \pm 0.07^{\mathrm{c}}$ \\
Snef1910-uninoculated & $46.98 \pm 1.76^{\mathrm{a}}$ & $16.90 \pm 1.08^{\mathrm{a}}$ & $8.28 \pm 0.92^{\mathrm{a}}$ & $0.95 \pm 0.08^{\mathrm{a}}$ \\
Snef1910-inoculated & $42.53 \pm 3.10^{\mathrm{b}}$ & $14.45 \pm 2.12^{\mathrm{b}}$ & $7.04 \pm 0.51^{\mathrm{b}}$ & $0.78 \pm 0.08^{\mathrm{b}}$ \\
\hline
\end{tabular}

The effects of $T$. citrinoviride Snef1910 on the growth parameters of tomato plants in the pot experiment was determined, 30 days post-inoculation. The data are the averages \pm standard error from ten replicates. Different letters represent a significant difference at $P \leq 0.05$ 
Table 4 The biocontrol effect of T. citrinoviride Snef1910 against M. incognita in the field experiment

\begin{tabular}{llllll}
\hline Treatments & \multicolumn{2}{l}{ August to September in $\mathbf{2 0 1 9}$} & & \multicolumn{2}{l}{ November to December in 2019} \\
\cline { 2 - 3 } & Gall index & Biocontrol efficacy (\%) & & Gall index & Biocontrol efficacy (\%) \\
\hline Snef1910 & $42.67 \pm 2.31^{\mathrm{a}}$ & 50.77 & $37.78 \pm 3.85^{\mathrm{a}}$ & 52.77 \\
Control & $86.67 \pm 2.31^{\mathrm{b}}$ & - & $80.00 \pm 6.67^{\mathrm{b}}$ & - \\
\hline
\end{tabular}

The biocontrol effect of $T$. citrinoviride Snef1910 against root-knot nematode disease caused by $M$. incognita in the field experiments was determined, 30 days after transplantation. The data are the averages \pm standard error from ten replicates. Different letters represent a significant difference at $P \leq 0.05$

acetic acid isolated from culture filtrates of T. longibrachiatum showed nematicidal activity against Meloidogyne spp. [37]. Many biocontrol activators obtained from Trichoderma spp. have been proven to be nematicidal compounds such as trichodermin and trypsin-like protease [38-41]. Our results indicated that cultural filtrates of $T$. citrinoviride Snef1910 strain showed high ovicidal and larvicidal activities (Fig. 1, 2). Further research will be conducted to identify and characterize the nematicidal compounds of T. citrinoviride Snef1910 against M. incognita.

The effective ways of biocontrol products and microorganism application should be applied according to the characteristics of the biocontrol agents and the routine practices of agricultural producers [42]. For example, the soil treatment with the culture broth of $B$. subtilis isolate B10 was highly significant in decreasing number of galls and egg masses of $M$. incognita with reduction percentage of 81.1 and $89.5 \%$, respectively [43]. Application of the fermentation broth of five bacterial strains by coating tomato seeds showed high biocontrol efficacy against $M$. incognita [26]. Moreover, soil treatment with the biocontrol agents T. harzianum and $T$. viride improved the efficiency of nematode control by reductions of up to $30.8 \%$ in nematode galling on tomato [27, 44]. Na et al. [5] reported that drenching of the broth containing spores was the appropriate application method for S. rubrogriseus HDZ-9-47 to control M. incognita, which reduced the root knot index and J2s density by 51.1 and $80.7 \%$, respectively. In this study, $T$. citrinoviride

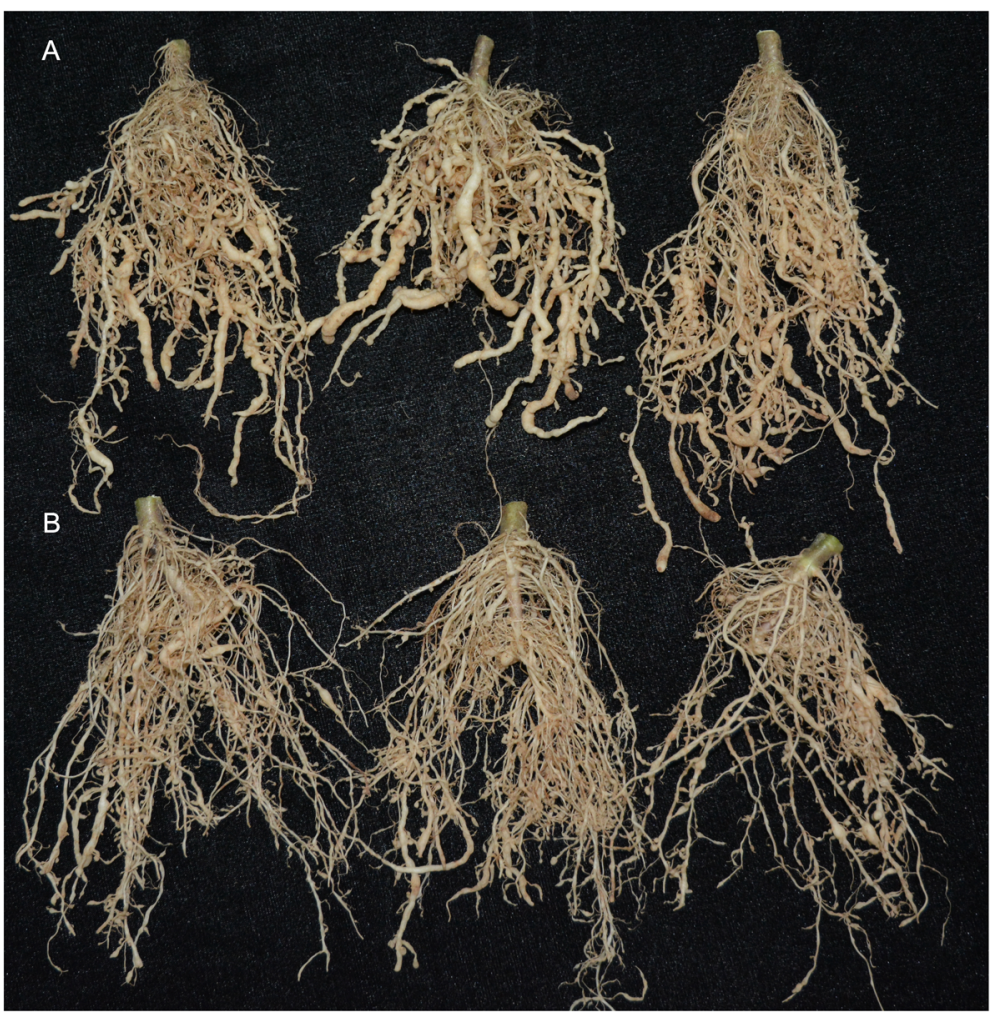

Fig. 5 Biocontrol of T. citrinoviride Snef1910 against M. incognita in the field experiment from November to December in 2019. a The M. incognita infected tomato plant roots, $\mathbf{b}$ the biocontrol effect of T. citrinoviride Snef1910 on tomato plant roots. Root gall indices were rated using a scale of $0-5$, where 0 , no gall; $1,15 \%$ or less roots with galls; $2-4,16-25 \%$; $26-50 \% ; 51-75 \%$ roots with galls, respectively; and $5,>76 \%$ roots with galls. Gall index $=\sum$ the number of diseased plants in each grade $\times$ grade/(total number of plants investigated $\times$ the highest grade) $\times 100 \%$. Biocontrol efficacy $(\%)=$ (gall index in the control - gall index in the Snef1910-treated group)/ gall index in the control $\times 100$ 
Table 5 The effect of T. citrinoviride Snef1910 on the growth parameters of tomato plants infected with M. incognita in the field experiments

\begin{tabular}{llllllll}
\hline Treatments & \multicolumn{2}{l}{ August to September in $\mathbf{2 0 1 9}$} & & \multicolumn{4}{l}{ November to December in 2019} \\
\cline { 2 - 4 } \cline { 6 - 8 } & Shoot length $(\mathbf{c m})$ & Root length $(\mathbf{c m})$ & Root fresh weight $\mathbf{( g )}$ & & Shoot length $(\mathbf{c m})$ & Root length $(\mathbf{c m})$ & Root fresh weight $(\mathbf{g})$ \\
\hline Snef1910 & $99.40 \pm 1.14^{\mathrm{a}}$ & $17.80 \pm 0.84^{\mathrm{a}}$ & $47.55 \pm 5.28^{\mathrm{a}}$ & & $91.20 \pm 1.30^{\mathrm{a}}$ & $16.00 \pm 0.71^{\mathrm{a}}$ & $8.35 \pm 1.38^{\mathrm{a}}$ \\
Control & $86.00 \pm 2.24^{\mathrm{b}}$ & $14.60 \pm 1.67^{\mathrm{b}}$ & $73.86 \pm 4.32^{\mathrm{b}}$ & & $73.20 \pm 4.09^{\mathrm{b}}$ & $14.20 \pm 1.48^{\mathrm{b}}$ & $12.52 \pm 2.82^{\mathrm{b}}$ \\
\cline { 1 - 2 }
\end{tabular}

The effects of $T$. citrinoviride Snef1910 on the growth parameters of tomato plants in the pot experiment was determined, 30 days after transplantation. The data are the averages \pm standard error from ten replicates. Different letters represent a significant difference at $P \leq 0.05$

Snef1910 significantly reduced the galls and nematodes in the pot and field trials through application the fermentation broth (Tables 2, 4). Therefore, drenching the fermentation broth is one of the application approaches for T. citrinoviride Snef1910 to control RKN. Meanwhile, other application such as seed coating of T. citrinoviride Snef1910 will be expected to study in the future.

Moreover, the plant growth promotion is well characterized in Trichoderma species. For example, T. harzianum T969 increased the shoot height (58.70\%), shoot diameter (58.03\%), root fresh weight $(78.92 \%)$ and dry weight (93.07\%) of tomato seedlings [45]. The mechanisms of Trichoderma in promoting plant growth also involve the production of auxin-like compounds, improving availability of nutrients, affecting root system, and inducing of systemic resistance phenomenon [46-49]. For example, the releasing an auxin-like phytohormone of $T$. harzianum SQR-T037 significantly promoted tomato seedling growth by up to 2.5 -fold dry weight [46]. In this study, T. citrinoviride Snef1910 resulted in increased plant growth of tomato in the pot and field experiments (Tables 3, 5). More work is also planned to explore the growth promotion effects and mechanisms of T. citrinoviride Snef1910 in tomato and even other plants.

\section{Conclusions}

In conclusion, this study showed that $T$. citrinoviride Snef1910 was screened from 890 fungi isolates and efficiently controlled RKN disease caused by M. incognita, which played control efficacy of more than $50 \%$ and increased egg hatching inhibition percentages and reduced root galls, egg masses and J2s on tomato. Moreover, T. citrinoviride Snef1910 showed the plant growth promotion of shoot and root length of tomato. This is the first report on the use of a $T$. citrinoviride strain as a potential biological control source to control RKN disease caused by $M$. incognita. This study provides a new biological control agent and potentially practical strategies for sustainable management of RKN.

\section{Methods}

\section{Isolation of fungal strains}

Fungal strains used in this study were originally isolated from rhizosphere soil collected from health plants including tomatoes, cucumbers, soybean, eggplant, peanut, and corn in different locations in northeast China. For fungal isolation, the soil serial dilution plate method was used [50]. In brief, a $1 \mathrm{~g}$ of rhizosphere soil samples was added into $9 \mathrm{~mL}$ of sterilized water and then mixed to obtain soil suspension. The soil suspension was serially diluted to the appropriate concentration $\left(10^{-2} \mathrm{~g} / \mathrm{mL}\right.$ and $10^{-3} \mathrm{~g} / \mathrm{mL}$ ) and plated on Potato Dextrose Agar (PDA) plates. The plates were then incubated at $28{ }^{\circ} \mathrm{C}$ for 5 days. Individual fungal colonies were isolated and purified.

\section{Preparation of nematode inoculum}

The root-knot nematode $M$. incognita, which sampled from the invasive tomato field located in Tieling County (123.92E, 42.18 N), Liaoning Province, China, was maintained on tomato plants in the greenhouse of Nematology Institute of Northern, Shenyang Agricultural University, China. Eggs were separated from masses that collected from the roots of tomato plants according to the method of Martinuz et al. [51]. The J2s were obtained by incubating the eggs in sterile water at $25^{\circ} \mathrm{C}$ for 5 days and collected every $24 \mathrm{~h}$. Then, the J2s were diluted to the appropriate concentration and used for further study.

\section{Screening of fungal isolates against $M$. incognita in vitro}

The J2s of $M$. incognita were used to detect the nematicidal activities of fungal isolates. The fermentation broth of fungal strains was prepared in Potato Dextrose Broth (PDB) medium in a shaker at $150 \mathrm{rpm}$ for 5 days at $28^{\circ} \mathrm{C}$. Cell-free supernatant was obtained after centrifugation at $4500 \times \mathrm{g}$ for $15 \mathrm{~min}$ and filtered using the filter $(\phi=0.45 \mu \mathrm{m})$. A $50 \mu \mathrm{L}$ suspension containing $50 \mathrm{~J} 2 \mathrm{~s}$ was added into each petri dish with $950 \mu \mathrm{L}$ of the prepared fungal cell-free supernatant. The J2s suspension mixed with PDB medium alone was used as control. Five dishes were used for each treatment. All the dishes were incubated at $25^{\circ} \mathrm{C}$ for $72 \mathrm{~h}$. The number of dead and alive J2s was examined using the stereoscopic microscope at $24 \mathrm{~h}, 48 \mathrm{~h}$, and $72 \mathrm{~h}$ after treatment. A nematode that malformed, immobile or motionless even probed with a fine needle was deemed dead [52]. The J2s mortality and corrected J2s mortality were calculated as following:

$\mathrm{J} 2 \mathrm{~s}$ mortality $(\%)=$ the number of dead J2s/total number of J2s $\times 100$. 
Corrected J2s mortality $(\%)=(\mathrm{J} 2 \mathrm{~s}$ mortality in the treatment

-J2s mortality in the control)

$/(100-J 2 s$ mortality in the control $) \times 100$

The strains that exhibited the strongest nematicidal activity against J2s of $M$. incognita were chosen for the future study. The effects of selected strains on J2s mortality of $M$. incognita were conducted as described above and repeated three times.

\section{In vitro antagonism test}

The dual culture technique was used to detect the antagonistic activities of strain Snef1910 against fungal plant pathogens (Fusarium graminearum, F. oxysporum, F. moniliforme, F. roseum, Gaeumannomyces graminis, Rhizoctonia cerealis, Verticillium alboatrum) [53]. In brief, the pathogen discs ( $5 \mathrm{~mm}$ diameter) were placed on one side of PDA plates $(90 \mathrm{~mm})$ around the center at a distance of $3 \mathrm{~cm}$. The plugs of strain Snef1910 was placed on the opposite side and around the fungal inocula at a distance of $6 \mathrm{~cm}$. PDA plates inoculated with the pathogen alone were used as a control. The plates were incubated at $28^{\circ} \mathrm{C}$ for 5 days. The antagonistic activity of strain Snef1910 was assessed by measuring the colony diameters. The percentage of growth inhibition was calculated using the formula $\mathrm{R}=(\mathrm{a}-\mathrm{b}) / \mathrm{a} \times 100$, where $\mathrm{R}, \mathrm{a}$, and $\mathrm{b}$ is the percentage of growth inhibition, the mycelial radial growth of the pathogen in the control and in the presence of the antagonist, respectively. The values were recorded as the means of three replicates, and the experiments were repeated three times. The 7 plant pathogens tested in this study were kindly provided by the College of Plant Protection, China Agricultural University, China.

\section{Testing the ovicidal efficacy of strain Snef1910 against $M$. incognita in vitro}

The ovicidal efficacy of strain Snef1910 against M. incognita was performed as previously described [26]. In short, 200 eggs were carefully added to $500 \mu \mathrm{L}$ of strain Snef1910 metabolites in each well of 96-well microtiter plates. Eggs transferred into PDB medium alone were used as controls. The plates were incubated at $28^{\circ} \mathrm{C}$ for $96 \mathrm{~h}$. In order to stop further hatching, $500 \mu \mathrm{L}$ of Lugol's iodine solution was added to each well [25]. The numbers of the unhatched eggs were counted under microscope [5], which were used to calculate the hatching percentage, hatch inhibition and corrected egg inhibition by the following formula:

Egg hatching percentage $(\%)=$ the number of hatched eggs $/$ total number of eggs $\times 100$.
Hatch inhibition $(\%)=$ (the number of hatched eggs in the control

- the number of hatched eggs in the fungus - treated group)

/the number of hatched eggs in the control $\times 100$.

Corrected egg inhibition $(\%)=($ The hatch inhibition in the treatment

- the hatched inhibition in control)

/(100 - hatch inhibition in the control $)$

Three wells were used for each replicate, and the values were recorded as the means of three replicates for each treatment. Ovicidal experiments were repeated three times.

\section{Identification of strain Snef1910}

To identify strain Snef1910, the growth pattern and microscopic observation of the morphology of conidia and conidiophores were performed. Single spore of strain Snef1910 was grown on the PDA plate at $25^{\circ} \mathrm{C}$ for 5 days. Then, a 5 -mm-diameter fungal plug was placed in the center of PDA plates $(90 \mathrm{~mm})$ at $25^{\circ} \mathrm{C}$ in the dark for 7 days. The color, smell, growth, and shape of the colony and conidiophores branching pattern and conidia were examined $[54,55]$.

Afterwards, strain Snef1910 was further identified through a phylogenetic analysis of its 5.8S-ITS region sequence. Genomic DNA of Snef1910 strain was extracted using a N96 Plant Genomic DNA Kit (Tiangen Biotech Co., Ltd., Beijing, China) according to the manufacturer's instructions. The fragment of 5.8S-ITS region was amplified with primer pair ITS1 and ITS4 [56]. The PCR product was ligated into the pMD19-T vector (Takara Co., Ltd., Dalian, China), and the resulting recombinant plasmid was sent to Shanghai Sangon Biotechnology Co., Ltd. (Shanghai, China) for sequencing. The phylogenetic tree of strain Snef1910 based on the sequence of 5.8S-ITS region was constructed using the neighborjoining method in MEGA 4.0 software [57]. The topology of the phylogenetic tree was evaluated using1000 bootstrap resampling replicates.

Biocontrol of root-knot nematode in the pot experiments The tomato (Solanum lycopersicum cultivar L-402 susceptible to $M$. incognita) was used to evaluate the biocontrol potentials of strain Snef1910. Tomato seeds were surface sterilized with $1 \%(\mathrm{v} / \mathrm{v})$ sodium hypochlorite solution for $5 \mathrm{~min}$, followed by 3 times washings with sterile distilled water [58]. Three seeds were sown in plastic pots $(5 \times 10$ holes) filled with $42 \mathrm{~g}$ of soil, vermiculite and sand at a ratio of 2:1:1. The sand and soils were autoclaved at $165^{\circ} \mathrm{C}$ for $120 \mathrm{~min}$ before planting. During the entire course of the experiment, the plants were watered two times and fertilized Hoagland solution once a week [24]. After attaining 2-leaf stage, the tomato seedlings were transplanted into $13 \mathrm{~cm} \times 12 \mathrm{~cm}$ plastic 
pots containing $600 \mathrm{~g}$ of autoclaved soil, sand and vermiculite at a ratio of 2:1:1 (one tomato seedling per pot). The pots were placed in a greenhouse under the following conditions: $28 \pm 2{ }^{\circ} \mathrm{C}, 60 \%$ humidity, and $16 \mathrm{~h}$ of light alternating with $8 \mathrm{~h}$ of darkness.

The fermentation broth $\left(2.15 \times 10^{6}\right.$ spores $\left./ \mathrm{mL}\right)$ of strain Snef1910 was prepared by the method described above. After transplanting for 2 days, each pot was treated with $2 \mathrm{~mL}$ fermentation broth of strain Snef1910. At the same time, each seedling was inoculated with 5 $\mathrm{mL}$ of $M$. incognita suspension containing 2000 motile J2s, and named Snef1910-inoculated. In addition, the following four treatments were maintained as controls: untreated + uninoculated control (untreated-uninoculated), untreated-uninoculated + inoculated $M$. incognita (untreated-inoculated), $2 \mathrm{~mL}$ of fermentation broth of strain Snef1910-uninoculated (Snef1910-uninoculated), and 2 $\mathrm{mL}$ PDB culture medium-inoculated (PDB culture medium-inoculated). The fermentation broth of strain Snef1910 and PDB culture medium filtrate in treatments of PDB culture medium-inoculated, Snef1910-uninoculated, and Snef1910-inoculated were suspended in $100 \mathrm{~mL}$ of sterile distilled water and applied by drenching roots. Each treatment included 10 replicates, and each replicate included one tomato plant. The experimental design for pot assay was performed a randomized complete block design.

Thirty days after inoculation, the tomato plants with their rhizosphere soil samples were collected. To evaluate the biocontrol potentials of strain Snef1910, shoot length, root length, fresh and dry weights of root, the number of root galls, J2s and egg masses per $1 \mathrm{~g}$ root, and J2s per $100 \mathrm{~mL}$ soil were counted as previously described $[26,59]$. The experiments were repeated three times.

\section{Biocontrol of root-knot nematode in the field experiment} The field experiment was carried out in a field naturally and severely infested with $M$. incognita, located in Tieling County, Liaoning Province, China (123.92E, 42.18 N) in two growing seasons (from August to September and November to December) in 2019 with the temperature ranged from $15^{\circ} \mathrm{C}$ to $35^{\circ} \mathrm{C}$. The soil in protected field was determined as a brown soil with the properties of $\mathrm{pH} 5.56 \pm 0.08$, organic matter $70.76 \mathrm{~g} / \mathrm{kg}$, and total nitrogen, available potassium, and available phosphorus of $4.56,285.95$, and $81.68 \mathrm{mg} / \mathrm{kg}$, respectively. The fourweek-old tomato seedlings without infestation with $M$. incognita were transplanted into the field. The $196 \mathrm{~mL}$ sterile distilled water was added into $4 \mathrm{~mL}$ fermentation broth $\left(10^{6}\right.$ spores $\left./ \mathrm{mL}\right)$ of strain Snef1910 or $4 \mathrm{~mL}$ PDB culture medium to obtain the desired concentrations and poured into the planting hole during plant transplantation. The experimental plots were $6 \mathrm{~m}$ long, $5.5 \mathrm{~m}$ wide and separated by $0.5 \mathrm{~m}$ (6 plant rows) and contained 21 transplanted seedlings per row. A randomized complete block design was adopted in this experiment, and each treatment consisted of three replications. The protected fields were irrigated and fertilized followed by farming practice.

Fifteen plants and rhizosphere soil samples were randomly selected and collected form each treatment, 30 days after transplantation. The shoot length, root length, and fresh weight of root were measured as described above. Root gall indices were rated using a scale of $0-5$, where 0 , no gall; $1,15 \%$ or less roots with galls; $2-4,16-$ $25 \%$; $26-50 \%$; $51-75 \%$ roots with galls, respectively; and $5,>76 \%$ roots with galls [60]. The root gall index and biocontrol efficacy were calculated as follow:

$$
\begin{aligned}
\text { Gall index }=\sum & \text { the number of diseased plants in each grade } \\
& \times \text { grade } /(\text { total number of plants investigated } \\
& \times \text { the highest grade }) \times 100 \% .
\end{aligned}
$$

Biocontrol efficacy $(\%)=($ gall index in the control

$$
\text { - gall index in the Snef1910 - treated group) }
$$$$
\text { /gall index in the control } \times 100 \text {. }
$$

\section{Statistical analysis}

Data were statistically analyzed using SPSS software 20.0. Duncan's one-way analysis of variance was used to determine the significant differences.

\section{Supplementary information}

Supplementary information accompanies this paper at https://doi.org/10. 1186/s12866-020-01984-4

Additional file 1: Table S1. The effect of fermentation broth of 890 fungi strains on second stage juvenile (J2s) mortality of $M$. incognita in vitro at $24 \mathrm{~h}$.

\section{Abbreviations}

J2s: Second stage juveniles; PCR: Polymerase Chain Reaction; PDA: Potato Dextrose Agar; PDB: Potato Dextrose Broth; RKN: Root-knot nematode

\section{Acknowledgments}

We thank Prof. Yue Liang (Shenyang Agricultural University) for assistance on the identification of strain Snef1910 experiments. We also thank Tantan Gao (Beijing University of Agriculture) for comments during the preparation of this manuscript.

\section{Authors' contributions}

HYF carried out the identification of strain Snef1910 and Biocontrol of root-knot nematode in the field experiments, data collection and analysis, and wrote a manuscript draft. MLY carried out the main experiments and data collection. HMW participated in biocontrol of root-knot nematode in the field experiment. DZ participated in the identification of strain Snef1910. XFZ participated in experimental design and revised the manuscript. YYW participated in biocontrol of root-knot nematode in the pot experiment. XYL participated in biocontrol of root-knot nematode in the field experiment. YXD participated in experimental design and revised the manuscript. $\amalg C$ guided experimental design. All authors read and approved the final manuscript.

\section{Funding}

This work was financially supported by National Key Research and Development Program of China (Grant No. 2017YFD021104), Liaoning 
Doctoral Research Foundation Project (Grant No. 2019-BS-210), National Natural Science Foundation of China (Grant No. 31901927), and Educational Commission of Liaoning Province (Grant No. LSNQN201723). The funding bodies had no role in the design of the study, in the collection, analysis, interpretation of data, or in the writing of the manuscript.

\section{Availability of data and materials}

The datasets used and analysed during the current study are available from the corresponding author on reasonable request. All data generated or analysed during this study are included in this article.

\section{Ethics approval and consent to participate}

Not applicable.

\section{Consent for publication}

Not applicable.

\section{Competing interests}

The authors declare that they have no competing interests.

\section{Author details}

${ }^{1}$ Nematology Institute of Northern China, College of Plant Protection, Shenyang Agricultural University, Shenyang, China. ${ }^{2}$ Analytical and Testing Center, Shenyang Agricultural University, Shenyang, China. ${ }^{3}$ College of Biological Science and Technology, Shenyang Agricultural University, Shenyang, China. ${ }^{4}$ College of Sciences, Shenyang Agricultural University, Shenyang, China.

\section{Received: 8 April 2020 Accepted: 23 September 2020}

\section{Published online: 02 October 2020}

\section{References}

1. Jones JT, Haegeman A, Danchin EG, Gaur HS, Helder J, Jones MG, et al. Top 10 plant-parasitic nematodes in molecular plant pathology. Mol Plant Pathol. 2013;14(9):946-61.

2. Trudgill DL, Blok VC. Apomictic, polyphagous root-knot nematodes: exceptionally successful and damaging biotrophic root pathogens. Ann Rev Phytopathol. 2001;39(1):53-77.

3. d'Errico G, Crescenzi A, Landi S. First report of the southern root-knot nematode Meloidogyne incognita on the invasive weed Araujia sericifera in Italy. Plant Dis. 2014;98(11):1593-4.

4. Castagnone-Sereno P, Danchin EG, Perfus-Barbeoch L, Abad P. Diversity and evolution of root-knot nematodes, genus Meloidogyne: new insights from the genomic era. Ann Rev Phytopathol. 2013:51:203-20.

5. Na J, Hui X, LI W-J, WANG X-Y, Qian L, LIU S-S, Pei L, J-I ZHAO, Heng J. Field evaluation of Streptomyces rubrogriseus HDZ-9-47 for biocontrol of Meloidogyne incognita on tomato. J Integr Agric. 2017;16(6):1347-57.

6. Sharifazizi M, Harighi B, Sadeghi A. Evaluation of biological control of Erwinia amylovora, causal agent of fire blight disease of pear by antagonistic bacteria. Biol Control. 2017;104:28-34.

7. Vega FE. The use of fungal entomopathogens as endophytes in biological control: a review. Mycologia. 2018;110(1):4-30.

8. Bunbury-Blanchette AL, Walker AK. Trichoderma species show biocontrol potential in dual culture and greenhouse bioassays against Fusarium basal rot of onion. Biol Control. 2019:130:127-35.

9. Sarwar A, Latif Z, Zhang S, Zhu J, Zechel D, Bechthold A. Biological control of potato common scab with rare isatropolone C compound produced by plant growth promoting Streptomyces A1RT. Front Microbiol. 2018:9:1126.

10. d'Errico G, Marra R, Crescenzi A, Davino SW, Fanigliulo A, Woo SL, Lorito M. Integrated management strategies of Meloidogyne incognita and Pseudopyrenochaeta lycopersici on tomato using a Bacillus firmus-based product and two synthetic nematicides in two consecutive crop cycles in greenhouse. Crop Prot. 2019;122:159-64.

11. Aiello D, Restuccia C, Stefani E, Vitale A, Cirvilleri G. Postharvest biocontrol ability of Pseudomonas synxantha against Monilinia fructicola and Monilinia fructigena on stone fruit. Postharvest Biol Technol. 2019;149:83-9.

12. Bhuiyan S, Garlick K, Anderson J, Wickramasinghe P, Stirling G. Biological control of root-knot nematode on sugarcane in soil naturally or artificially infested with Pasteuria penetrans. Australas Plant Pathol. 2018;47(1):45-52.

13. Rao M, Kamalnath M, Umamaheswari R, Rajinikanth R, Prabu P, Priti K, Grace G, Chaya M, Gopalakrishnan C. Bacillus subtilis IIHR BS-2 enriched vermicompost controls root knot nematode and soft rot disease complex in carrot. Sci Horticulturae. 2017:218:56-62.

14. Mukhtar T. Management of root-knot nematode, Meloidogyne incognita, in tomato with two Trichoderma species. Pak J Zool. 2018;50(4):1589-92.

15. Ghahremani Z, Escudero N, Saus E, Gabaldon T, Javier Sorribas F. Pochonia chlamydosporia induces plant-dependent systemic resistance to Meloidogyne incognita. Front Plant Sci. 2019;10:945.

16. Huang W-K, Cui J-K, Liu S-M, Kong L-A, Wu Q-S, Peng H, He W-T, Sun J-H, Peng D-L. Testing various biocontrol agents against the root-knot nematode (Meloidogyne incognita) in cucumber plants identifies a combination of Syncephalastrum racemosum and Paecilomyces lilacinus as being most effective. Biol Control. 2016;92:31-7.

17. Vinale F, Sivasithamparam K, Ghisalberti EL, Marra R, Woo SL, Lorito M. Trichoderma-plant-pathogen interactions. Soil Biol Biochem. 2008;40(1):1-10.

18. Ozbay N, Newman SE. Biological control with Trichoderma spp. with emphasis on T. harzianum. Pak J Biol Sci. 2004;7(4):478-84.

19. Dukare AS, Paul S, Nambi VE, Gupta RK, Singh R, Sharma K, Vishwakarma RK Exploitation of microbial antagonists for the control of postharvest diseases of fruits: a review. Crit Rev Food Sci Nutr. 2019;59(9):1498-513.

20. Bae S-J, Mohanta TK, Chung JY, Ryu M, Park G, Shim S, et al. Trichoderma metabolites as biological control agents against Phytophthora pathogens. Biol Control. 2016;92:128-38.

21. Giurgiu RM, Dumitraș A, Morar G, Scheewe P, Schroeder FG. A study on the biological control of Fusarium oxysporum using Trichoderma spp., on soi and rockwool substrates in controlled environment. Notulae Botanicae Horti Agrobotanici Cluj-Napoca. 2018;46(1):260-9.

22. Sonkar SS, Bhatt J, Meher J, Kashyap P. Bio-efficacy of Trichoderma viride against the root-knot nematode (Meloidogyne incognita) in tomato plant. J Pharmacognosy Phytochemistry. 2018;7(6):2010-4.

23. Affokpon A, Coyne DL, Htay CC, Agbèdè RD, Lawouin L, Coosemans J. Biocontrol potential of native Trichoderma isolates against root-knot nematodes in West African vegetable production systems. Soil Biol Biochem. 2011:43(3):600-8

24. Martínez-Medina A, Fernandez I, Lok GB, Pozo MJ, Pieterse CM, Van Wees SC. Shifting from priming of salicylic acid-to jasmonic acid-regulated defences by Trichoderma protects tomato against the root knot nematode Meloidogyne incognita. New Phytol. 2017;213(3):1363-77.

25. Saikia SK, Tiwari S, Pandey R. Rhizospheric biological weapons for growth enhancement and Meloidogyne incognita management in Withania somnifera cv. Poshita. Biol Control. 2013;65(2):225-34.

26. Zhao D, Zhao H, Zhao D, Zhu X, Wang Y, Duan Y, Xuan Y, Chen L. Isolation and identification of bacteria from rhizosphere soil and their effect on plant growth promotion and root-knot nematode disease. Biol Control. 2018;119:12-9.

27. Dababat AA, Sikora RA, Hauschild R. Use of Trichoderma harzianum and Trichoderma viride for the biological control of Meloidogyne incognita on tomato. Commun Agric Appl Biol Sci. 2006;71(3 Pt B):953-61.

28. Sharon E, Bareyal M, Chet I, Herreraestrella A, Kleifeld O, Spiegel Y. Biological control of the root-knot nematode Meloidogyne javanica by Trichoderma harzianum. Phytopathology. 2001:91(7):687-93.

29. Zhang S, Gan Y, Xu B. Biocontrol potential of a native species of Trichoderma longibrachiatum against Meloidogyne incognita. Appl Soil Ecol. 2015;94:21-9.

30. Hhmau H, Wijesundera R, Chandrasekharan N, Wijesundera W, Kathriarachchi $\mathrm{H}$. Isolation and characterization of Trichoderma erinaceum for antagonistic activity against plant pathogenic fungi. Curr Res Environ Appl Mycol. 2015;5(2):120-7.

31. Benitez T, Rincon AM, Limon MC, Codon AC. Biocontrol mechanisms of Trichoderma strains. Int Microbiol. 2004;7(4):249-60.

32. Ragozzino A, d'Errico G. Interactions between nematodes and fungi: A concise review. Redia. 2011:94:123-5.

33. Lombardi N, Vitale S, Turra D, Reverberi M, Fanelli C, Vinale F, Marra R, Ruocco M, Pascale A, d'Errico G, Woo SL, Lorito M. Root exudates of stressed plants stimulate and attract Trichoderma soil fungi. Mol Plant Microbe Interact. 2018:31(10):982-94.

34. Xiao-Yan S, Qing-Tao S, Shu-Tao X, Xiu-Lan C, Cai-Yun S, Yu-Zhong Z. Broadspectrum antimicrobial activity and high stability of Trichokonins from Trichoderma koningii SMF2 against plant pathogens. FEMS Microbiol Lett. 2006:260(1):119-25.

35. Hermosa R, Cardoza RE, Rubio MB, Gutiérrez S, Monte E. Secondary metabolism and antimicrobial metabolites of Trichoderma. In: Gupta VK, Schmoll M, Herrera-Estrella A, Upadhyay RS, Druzhinina I, Tuohy MG, editors. 
Biotechnol Biol Trichoderma. Chapter 10. Waltham: Elsevier; 2014. p. 125-37.

36. Reino JL, Guerrero RF, Hernández-Galán R, Collado IG. Secondary metabolites from species of the biocontrol agent Trichoderma. Phytochemistry Rev. 2008;7(1):89-123.

37. Favre-Bonvin J, Ponchet M, Djian C, Arpin N, Pijarowski L. Acetic acid: a selective nematicidal metabolite from culture filtrates of Paecilomyces lilacinus (Thom) Samson and Trichoderma longibrachiatum Rifai. Nematologica. 1991;37(1-4):101-12.

38. Yang Z-S, Li G-H, Zhao P-J, Zheng X, Luo S-L, Li L, Niu X-M, Zhang K-Q. Nematicidal activity of Trichoderma spp. and isolation of an active compound. World J Microbiol Biotechnol. 2010;26(12):2297-302.

39. Yang Z, Yu Z, Lei L, Xia Z, Shao L, Zhang K, Li G. Nematicidal effect of volatiles produced by Trichoderma sp. J Asia Pac Entomol. 2012;15(4):647-50.

40. Suarez B, Rey M, Castillo P, Monte E, Llobell A. Isolation and characterization of PRA1, a trypsin-like protease from the biocontrol agent Trichoderma harzianum CECT 2413 displaying nematicidal activity. Appl Microbiol Biotechnol. 2004;65(1):46-55.

41. Chen L-L, Liu L-J, Shi M, Song X-Y, Zheng C-Y, Chen X-L, Zhang Y-Z. Characterization and gene cloning of a novel serine protease with nematicidal activity from Trichoderma pseudokoningii SMF2. FEMS Microbiol Lett. 2009;299(2):135-42.

42. Ling N, Xue C, Huang Q, Yang X, Xu Y, Shen Q. Development of a mode of application of bioorganic fertilizer for improving the biocontrol efficacy to Fusarium wilt. Biocontrol. 2010;55(5):673-83.

43. Basyony AG, Abo-Zaid GA. Biocontrol of the root-knot nematode, Meloidogyne incognita, using an eco-friendly formulation from Bacillus subtilis, lab. and greenhouse studies. Egypt J Biol Pest Control. 2018;28:UNSP 87.

44. Goswami J, Pandey RK, Tewari J, Goswami B. Management of root knot nematode on tomato through application of fungal antagonists, Acremonium strictum and Trichoderma harzianum. J Environ Sci Health Part B. 2008:43(3):237-40

45. Azarmi R, Hajieghrari B, Giglou A. Effect of Trichoderma isolates on tomato seedling growth response and nutrient uptake. Afr J Biotechnol. 2011;10(31): 5850-5.

46. Cai F, Yu G, Wang P, Wei Z, Fu L, Shen Q, Chen W. Harzianolide, a novel plant growth regulator and systemic resistance elicitor from Trichoderma harzianum. Plant Physiol Biochem. 2013;73:106-13.

47. Angel Contreras-Cornejo H, Macias-Rodriguez L, Cortes-Penagos C, LopezBucio J. Trichoderma virens, a plant beneficial fungus, enhances biomass production and promotes lateral root growth through an auxin-dependent mechanism in Arabidopsis. Plant Physiol. 2009;149(3):1579-92.

48. Li R-X, Cai F, Pang G, Shen Q-R, Li R, Chen W. Solubilisation of phosphate and micronutrients by Trichoderma harzianum and its relationship with the promotion of tomato plant growth. PLoS One. 2015;10(6):e0130081.

49. Marra R, Lombardi N, d'Errico G, Troisi J, Scala G, Vinale F, Woo SL, Bonanomi G, Lorito M. Application of Trichoderma strains and metabolites enhances soybean productivity and nutrient content. J Agric Food Chem. 2019;67(7):1814-22.

50. Pradhan N, Sukla LB. Solubilization of inorganic phosphates by fungi isolated from agriculture soil. Afr J Biotechnol. 2006;5(10):850-4.

51. Martinuz A, Zewdu G, Ludwig N, Grundler F, Sikora RA, Schouten A. The application of Arabidopsis thaliana in studying tripartite interactions among plants, beneficial fungal endophytes and biotrophic plant-parasitic nematodes. Planta. 2015;241(4):1015-25.

52. Cayrol JC, Djian C, Pijarowski L. Study of the nematicidal properties of the culture filtrate of the nematophagous fungus Paecilomyces lilacinus. Rev Nematol. 1989;12(4):331-6.

53. Pandian RTP, Raja M, Kumar A, Sharma P. Morphological and molecular characterization of Trichoderma asperellum strain Ta13. Indian Phytopathol. 2016;69(3):297-303.

54. Kim JY, Kwon HW, Tang L, Kim SH. Identification and characterization of Trichoderma citrinoviride isolated from mushroom fly-infested oak log beds used for shiitake cultivation. Plant Pathol J. 2012;28(2):219.

55. Kumar K, Amaresan N, Bhagat S, Madhuri K, Srivastava RC. Isolation and characterization of Trichoderma spp. for antagonistic activity against root rot and foliar pathogens. Indian J Microbiol. 2012;52(2):137-44.

56. White TJ, Bruns T, Lee S, Taylor J. Amplification and direct sequencing of fungal ribosomal RNA genes for phylogenetics. PCR Protoc Guide Methods Appl. 1990;18(1):315-22.
57. Tamura K, Dudley J, Nei M, Kumar S. MEGA4: Molecular evolutionary genetics analysis (MEGA) software version 4.0. Mol Biol Evol. 2007;24(8): 1596-9.

58. Saharan V, Sharma G, Yadav M, Choudhary MK, Sharma S, Pal A, Raliya R, Biswas P. Synthesis and in vitro antifungal efficacy of Cu-chitosan nanoparticles against pathogenic fungi of tomato. Int J Biol Macromol. 2015;75:346-53.

59. Tiwari S, Pandey S, Chauhan PS, Pandey R. Biocontrol agents in coinoculation manages root knot nematode [Meloidogyne incognita (Kofoid \& White) Chitwood] and enhances essential oil content in Ocimum basilicum L. Ind Crops Prod. 2017:97:292-301.

60. Barker KR. Design of greenhouse and microplot experiments for evaluation of plant resistance to nematodes. In: Zuckerman BM, Mai WF, Harrison MB, editors. Plant Nematol Lab Man. Amherst: University of Massachussets Agriculture Experiment Station; 1985. p. 103-13.

\section{Publisher's Note}

Springer Nature remains neutral with regard to jurisdictional claims in published maps and institutional affiliations.

Ready to submit your research? Choose BMC and benefit from:

- fast, convenient online submission

- thorough peer review by experienced researchers in your field

- rapid publication on acceptance

- support for research data, including large and complex data types

- gold Open Access which fosters wider collaboration and increased citations

- maximum visibility for your research: over $100 \mathrm{M}$ website views per year

At BMC, research is always in progress.

Learn more biomedcentral.com/submissions 